\title{
A single cyanobacterial ribotype is associated with both red and black bands on diseased corals from Palau
}

\author{
Meir Sussman ${ }^{1,2, *}$, David G. Bourne ${ }^{2}$, Bette L. Willis ${ }^{1}$ \\ ${ }^{1}$ James Cook University, School of Marine Biology and Aquaculture, Townsville 4811, Queensland, Australia \\ ${ }^{2}$ Australian Institute of Marine Science, PMB 3, Townsville MC, Townsville 4810, Queensland, Australia
}

\begin{abstract}
Filamentous cyanobacteria forming red and black bands (black band disease, BBD) on 3 scleractinian corals from Palau were molecularly identified as belonging to a single ribotype. Red cyanobacterial mats sampled from infections on Pachyseris speciosa and a massive Porites sp. yielded red strains RMS1 and RMS2 respectively; the black cyanobacterial mat sampled from an infection on Montipora sp. yielded black strain BMS1. Following trials of a range of specialized media and culture conditions, 2 media, Grund and ASN-III, were identified as the best for successful isolation and culturing. Cultured cyanobacteria were examined under a light microscope to establish purity, color and morphological appearance. DNA extraction and partial sequencing of the 16S rDNA gene of both red and black cyanobacterial isolates demonstrated $100 \%$ sequence identity. These isolated strains were also found to have $99 \%$ sequence identity with an uncultured cyanobacterial strain previously identified by molecular techniques as belonging to a cyanobacterial ribotype associated with BBDinfected corals in the Caribbean. This is the first report of the successful isolation and culture of cyanobacterial strains derived from both red bands and BBD. Based on these findings, it is suggested that the classification of these 2 syndromes as separate coral diseases be postponed until further evidence is collected.
\end{abstract}

KEY WORDS: Coral disease - Black band disease $\cdot$ BBD $\cdot$ Red bands $\cdot$ Red band disease $\cdot$ RBD Cyanobacterial pigmentation

\section{INTRODUCTION}

Cyanobacteria are associated with at least 2 band diseases that are differentiated macroscopically primarily based on color: black band disease (BBD), the first coral disease to be identified (Antonius 1973); and red band disease (RBD), first reported by Rützler et al. (1983) and later by Richardson in the Bahamas (Richardson 1992, 1998). BBD is a band of filamentous cyanobacteria that progresses across live coral tissue, causing mortality of the coral along the advancing front (Antonius 1981). It has been recorded worldwide and is found on 21 species in the Caribbean (Weil 2004) and 40 species on the Great Barrier Reef (Page \& Willis 2006, this issue). RBD has been considered a separate disease category (Santavy \& Peters 1997, Gar- zon Ferreira et al. 2001) and has been recorded to affect 14 coral species in the Caribbean (Weil et al. 2002, Weil 2004). However, researchers have had little success in culturing the cyanobacteria associated with these putatively different coral diseases and, thus, it has not been possible to evaluate the significance of their color differences.

Early studies suggested that the causative agent of $\mathrm{BBD}$ is a consortium of microorganisms (reviewed in Richardson 2004). Phormidium corallyticum, a filamentous cyanobacterium from the genus Oscillatoria, was initially identified as the species forming the mat or band on infected corals (Ruetzler \& Santavy 1983, Taylor 1983). The band's black appearance was suggested to be caused by a high concentration of cells containing the light-harvesting red photosynthetic pig- 
ment phycoerythrin (Richardson 1997). Recent molecular analyses have failed to identify $P$. corallyticum and other proposed consortium members, such as the sulfide-oxidizing bacteria Beggiatoa sp., in the black mat of BBD-infected corals (Frias Lopez et al. 2004b). Another ribotype of cyanobacteria from the genus Oscillatoria was shown to be associated with BBDinfected corals from the Caribbean and Indo-Pacific (Cooney et al. 2002, Frias-Lopez et al. 2002, 2003). These conflicting findings have led to an uncertainty regarding the identity of the cyanobacteria associated with BBD and their role in causing infections (FriasLopez et al. 2004a,b).

Morphological observations of the cyanobacteria associated with red bands identified 2 filamentous strains within the genus Oscillatoria (Richardson 1992, 1998). These strains were reported as being visually distinct from Phormidium corallyticum, yet never identified to a species level. Rützler et al. (1983) visually identified Schizothrix calcicola and S. mexicana on corals displaying red bands. Sutherland et al. (2004) claimed that, due to lower prevalence in the field, red band might be grouped together with black band as a single classification. Harvell et al. (2004) were the first to publish a red band photo of an infected Pachyseris speciosa colony from Palau, emphasizing the need for further investigations. In recent surveys on the Great Barrier Reef, Willis et al. (2004) classified red bands and other cyanobacterial syndromes as part of a generalized cyanobacterial category, due to uncertainty regarding their taxonomic identity. Needless to say, not all cyanobacteria found on corals constitute a threat to coral health (see Lesser et al. 2004).

The aims of this study were to develop methods for culturing cyanobacteria associated with band diseases in corals and to determine whether cyanobacteria isolated from red bands and BBD are genetically different. Isolation and culturing of cyanobacteria from 1 black and 2 red bands on corals sampled from reefs in Palau (Micronesia) tested whether pigmentation was: (1) independent of strain-host interaction, and (2) stable under identical growth conditions. The results of this study establish the first link between color, morphology and molecular-based taxonomic identification of cyanobacterial strains isolated from both red bandand BBD-infected corals.

\section{MATERIALS AND METHODS}

Sample collection. Samples from 2 corals infected with red bands (Porites sp. and Pachyseris speciosa) and 1 infected with BBD (Montipora sp.) were collected using SCUBA on Indo-Pacific reefs surrounding the island of Palau in January 2004. Samples were sealed in plastic bags immediately after collection and transported to a laboratory at the Palau International Coral Reef Center (PICRC). Samples were processed within $2 \mathrm{~h}$ of collection. Red and black cyanobacteria associated with the microbial mat of each disease were sampled from the corals using sterile forceps, and transferred to agar plates.

Media and conditions of growth. Optimized conditions for growth of isolated cyanobacterial strains were determined by comparison of growth responses in 13 different media (see Table 1) under 2 light regimes. Media were chosen based on published recommendations for optimizing cyanobacterial growth in cultures (reviewed in McLachlan 1973). Cultures were incubated at $26^{\circ} \mathrm{C}$ under either a $12: 12 \mathrm{~h}$ light:dark fluorescent light regime or $24 \mathrm{~h}$ of constant fluorescent illumination, both at $15 \mu \mathrm{E} \mathrm{m}^{-2} \mathrm{~s}^{-1}$. Half the plates used in this trial were scored (Vaara et al. 1979). Scoring assists in purifying cultures from contaminants while selecting for motility, which is a key characteristic of cyanobacteria found on BBD- and red band-infected corals. Cultures were inspected daily and graded for growth on a scale from low growth $(+)$ to highest growth $(+++++)$ after a $7 \mathrm{~d}$ incubation period. The most successful media (Grund and ASN-III) and conditions (constant lighting/scored plates) (see Table 1 for summary of results) were chosen for studies of color expression under constant growth conditions.

Grund media (von Stosch 1963, 1969) consisted of enriched seawater (enriched with $10 \mathrm{mg} \mathrm{l}^{-1} \mathrm{CaCl}_{2}$, $4 \mathrm{mg} \mathrm{l}^{-1} \mathrm{Na}_{2} \mathrm{HPO}_{4}, 1 \mathrm{~g} \mathrm{l}^{-1} \mathrm{NaNO}_{3}, 2 \mathrm{mg} \mathrm{l}^{-1}$ disodium EDTA, $20 \mathrm{mg} \mathrm{l}^{-1} \mathrm{Na}_{2} \mathrm{CO}_{3}$ ) to which were added $1 \mathrm{ml}$ micronutrient solution $\left(\mathrm{A}_{5}+\mathrm{CO}\right)$ and $1 \mathrm{ml}$ vitamin solution (S-3) per liter of medium. The micronutrient solution $\mathrm{A}_{5}+\mathrm{CO}$ (Rippka et al. 1979) was made of a 1000x stock solution and filter sterilized $\left(2.86 \mathrm{~g} \mathrm{l}^{-1} \mathrm{H}_{3} \mathrm{BO}_{3}\right.$, $1.81 \mathrm{~g} \mathrm{l}^{-1} \mathrm{MnCl}_{2} \cdot 4 \mathrm{H}_{2} \mathrm{O}, 0.22 \mathrm{~g} \mathrm{l}^{-1} \mathrm{ZnSO}_{4} \cdot 7 \mathrm{H}_{2} \mathrm{O}$, $0.39 \mathrm{~g} \mathrm{l}^{-1} \mathrm{Na}_{2} \mathrm{MoO}_{4} \cdot 2 \mathrm{H}_{2} \mathrm{O}, 0.079 \mathrm{~g} \mathrm{l}^{-1} \mathrm{CuSO}_{4} \cdot 5 \mathrm{H}_{2} \mathrm{O}$, $\left.0.049 \mathrm{~g} \mathrm{l}^{-1} \mathrm{Co}\left(\mathrm{No}_{3}\right)_{2} \cdot 6 \mathrm{H}_{2} \mathrm{O}\right)$. The vitamin solution $\mathrm{S}-3$ (Provasoli 1963) was made as a $1000 \times$ stock solution filter sterilized and kept in the dark $\left(100 \mathrm{mg} \mathrm{l}^{-1}\right.$ nicotinic acid, $500 \mathrm{mg} \mathrm{l}^{-1}$ thiamine $\cdot \mathrm{HCl}, 100 \mathrm{mg} \mathrm{l}^{-1} \mathrm{Ca}$. pantothenate, $10 \mathrm{mg} \mathrm{l}^{-1}$ para-aminobenzoic acid (PABA), $1 \mathrm{mg} \mathrm{l}^{-1}$ biotin, $5 \mathrm{~g} \mathrm{l}^{-1}$ i-inositol, $2 \mathrm{mg} \mathrm{l}^{-1}$ folic acid, $1 \mathrm{mg} \mathrm{l}^{-1}$ cyanocobalamin, $3 \mathrm{~g} \mathrm{l}^{-1}$ thymine). In addition, $8 \mu \mathrm{M}$ of $\mathrm{Na}_{2}$-EDTA/FeCl ${ }_{3}$ were added to each liter of medium (Rippka et al. 2000). ASNIII, a synthetic medium developed by Waterbury \& Stanier (1981) was revised and made up of $1 \mathrm{l}$ double-distilled water (DDW), $427 \mathrm{mM} \mathrm{NaCl}, 6.7 \mathrm{mM} \mathrm{KCl}, 3.4 \mathrm{mM} \mathrm{CaCl}_{2}$, $14.2 \mathrm{mM} \mathrm{MgSO}_{4}, 9.8 \mathrm{mM} \mathrm{MgCl}{ }_{2}, 0.09 \mathrm{mM} \mathrm{K}_{2} \mathrm{HPO}_{4}$, $1 \mathrm{mM} \mathrm{NaNO}{ }_{3}, 0.19 \mathrm{mM} \mathrm{Na}_{2} \mathrm{CO}_{3}$. Eight $\mu \mathrm{M}$ of $\mathrm{Na}_{2}-$ EDTA $/ \mathrm{FeCl}_{3}, 1 \mathrm{ml}$ micronutrient solution $\left(\mathrm{A}_{5}+\mathrm{CO}\right)$ and $1 \mathrm{ml}$ vitamin solution (S-3) were added to each liter of medium. Agar plates were prepared using washed 
agar (Waterbury \& Willey 1988). A ×1.33 concentration (in $750 \mathrm{ml}$ ) of liquid media (Grund or ASN-III) was filtered using Millipore $1000 \mathrm{ml}^{\text {Stericup }}{ }^{\odot}$, preheated to $50^{\circ} \mathrm{C}$ and added to $250 \mathrm{ml}$ of autoclaved DDW with $6 \mathrm{~g}$ washed agar. Once dry, plates were scored with parallel lines using a flamed glass slide (Vaara et al. 1979) and incubated under unidirectional light. A liquid medium prepared from live coral tissue in seawater was also tested and found to enhance growth. This medium was autoclaved for $30 \mathrm{~min}$ and then sterile filtered (as above).

DNA extraction, PCR amplification and sequencing. DNA extraction was performed by a modified protocol from $\mathrm{Wu}$ et al. (2000). Following an initial growth phase of 10 to $14 \mathrm{~d}$, filaments from liquid media flasks were inspected under light microscopy for strain purity, color and morphology. A total of $200 \mathrm{mg}$ of cyanobacteria culture RMS1 (Pachyseris speciosa), RMS2 (Porites sp.) and BMS1 (Montipora sp.) were collected from each flask and placed in $2 \mathrm{ml}$ tubes with $1 \mathrm{ml}$ buffer A $(100 \mathrm{mM}$ Tris, $50 \mathrm{mM}$ EDTA, $100 \mathrm{mM}$ $\mathrm{NaCl}$ at $\mathrm{pH}$ 8) for $10 \mathrm{~min}$ at room temperature. N-lauroylsarcosine (sarkosyl) was added to a final concentration of $0.1 \%$ and the samples incubated overnight at $4^{\circ} \mathrm{C}$. Filaments were collected by centrifugation at $8000 \times g$ for $10 \mathrm{~min}$, washed in $2 \mathrm{ml}$ of TES (50 mM Tris, $5 \mathrm{mM}$ EDTA, $50 \mathrm{mM} \mathrm{NaCl}$ at $\mathrm{pH}$ 8), centrifuged again for $5 \mathrm{~min}$ and resuspended in $1 \mathrm{ml}$ TES. Lysozyme was added to a final concentration of $0.5 \mathrm{mg} \mathrm{ml}^{-1}$ and the sample incubated with RNase $\left(20 \mu \mathrm{g} \mathrm{ml}^{-1}\right)$ at $37^{\circ} \mathrm{C}$ for 30 to 90 min with shaking. Sodium dodecyl (lauryl) sulfate (SDS) was added to a final concentration of $1 \%$, stirred thoroughly, and kept at $37^{\circ} \mathrm{C}$ for $10 \mathrm{~min} .50 \mu \mathrm{g}$ $\mathrm{ml}^{-1}$ Proteinase $\mathrm{K}$ was added and the sample was incubated overnight at $4^{\circ} \mathrm{C}$ (or alternatively at $37^{\circ} \mathrm{C}$ for $1 \mathrm{~h}$ ). Extraction was performed using the Promega Wizard Genomic DNA purification $\mathrm{kit}^{\odot}$ starting with protein precipitation (Step 4 of Gram-negative protocol). After isopropanol and $70 \%$ ethanol precipitations, pellets were dried in a DNA110 Speed Vac (Savant) for $15 \mathrm{~min}$ and rehydrated overnight at $4{ }^{\circ} \mathrm{C}$. PCR amplification was performed following the protocol of Nübel et al. (1997). Cyanobacterial specific primers used were the CY106F forward primer (CGG ACG GGT GAG TAA CGC GTG A) and an equimolar mixture of CYA 781Ra (GAC TAC TGG GGT ATC TAA TCC CAT T) and CYA 781Rb (GAC TAC AGG GGT ATC TAA TCC $\mathrm{CTT}$ T) reverse primers. Reactions $(50 \mu \mathrm{l})$ were made of $10 \mathrm{pmol}$ of each primer, $5 \mu \mathrm{l}$ of $10 \times$ PCR buffer (Taq PCR Core Kit, Qiagen with $15 \mathrm{mM} \mathrm{MgCl}_{2}$ ), $50 \mathrm{nmol}$ dNTP, 10 ng of template DNA (1:10 dilution of stock). Q-Solution (Qiagen; $10 \mu \mathrm{l}$ ) was added to each tube and DDW to the volume of $50 \mu \mathrm{l}$. Taq (1 U) was added at $80^{\circ} \mathrm{C}$ to minimize nonspecific annealing of primers following a $5 \mathrm{~min}$ hot start at $94^{\circ} \mathrm{C}$. An Eppendorf Mas- tercycler ${ }^{\circledR}$ was used for template amplification with 35 cycles of $1 \mathrm{~min}$ at $94^{\circ} \mathrm{C}, 1 \mathrm{~min}$ at $60^{\circ} \mathrm{C}$ and $1 \mathrm{~min}$ at $72^{\circ} \mathrm{C}$. A final $5 \mathrm{~min}$ extension step at $72^{\circ} \mathrm{C}$ was performed. Reaction products were purified using DNAce Quick-Clean $^{\odot}$ and sequenced using ET-Terminators (Amersham Biosciences) on MegaBACE 1000 from Amersham Biosciences. Sequences were visualized using $\mathrm{CHROMAS}^{\odot}$ and aligned (Altschul et al. 1990) with existing database using BLAST (www.ncbi.nlm. nih.gov). Multiple alignments were performed using Baylor College of Medicine (BCM) multiple sequence alignments (www.imgen.bcm.tmc.edu). Partial 16S rDNA gene sequences were entered into the GenBank database under the following accession numbers: AY839639, AY839640, AY839641 (for further details see Table 2).

Light microscopy. Cyanobacterial filaments were examined using the Zeiss Axioshop 2 Mot Plus microscope equipped with an AxioCam MRC5 digital camera using AxioVision $4^{\odot}$ software. Cyanobacterial filaments were photographed prior to the sampling for DNA extraction. Since this study aims to compare pigmentation among cynaobacterial strains, no further software manipulation of AxioVision $4^{\odot}$ calibrated images has been undertaken, and they appear as identical replications of originals.

\section{RESULTS}

Media and conditions of growth. Thirteen different variations of solid and liquid media were evaluated in an attempt to isolate and grow filamentous cyanobacteria associated with infected corals. Cultures grew best in either Grund media (with seawater) or ASN-III media (Table 1). Cyanobacteria did not grow on, or in, any of the media devoid of nitrogen (PCR-S8, PCRS11, PCR-Tu2). This demonstrates that cyanobacteria found on red band- and BBD-infected corals do not fix nitrogen. Highest growth in liquid media (score: $+++++)$ was achieved in a zooxanthellae broth consisting of coral tissue autoclaved in seawater. At $26^{\circ} \mathrm{C}$ and using fluorescent lights $\left(15 \mu \mathrm{E} \mathrm{m} \mathrm{m}^{-2} \mathrm{~s}^{-1}\right)$, continuous $(24 \mathrm{~h})$ lighting provided better results than a 12:12 h light:dark regime.

Washing agar with ethanol and acetone, as suggested by Waterbury \& Willey (1988), and scoring plates (Vaara et al. 1979) facilitated the motility of cyanobacteria towards a unidirectional light source placed at an angle away from the plates. Both red and black cyanobacterial filaments in scored plates progressed along grooves at a speed of up to $5 \mathrm{~cm} \mathrm{~d}^{-1}$. Non-scored plates placed directly under light exhibited no growth. Supplementing the agar with $0.1 \%$ (w/v) $\mathrm{Na}_{2} \mathrm{~S}$ and raising $\mathrm{pH}$ to 9 (Vaara et al. 1979) did 
Table 1. Media and conditions of growth employed in this study to culture cyanobacteria associated with red band- and black band disease (BBD)-infected corals from Palaun reefs. Growth of cyanobacteria was scored qualitatively as follows: $(-)=$ no growth $;(+)=$ low growth; $(+++++)=$ highest growth. DDW: double-distilled water. Vitamin $\mathrm{S}-3 \times 1000$ solution was filtersterilized and kept in the dark. Volume of vitamin solution added: $1 \mathrm{ml} \mathrm{l}^{-1}$ medium. Volume of micronutrient $\mathrm{A}_{5}+\mathrm{Co}_{\mathrm{added}} 1 \mathrm{ml} \mathrm{\textrm {l } ^ { - 1 }}$ medium. For further details see 'Materials and methods' section

\begin{tabular}{|c|c|c|c|c|c|c|c|c|}
\hline \multirow[t]{3}{*}{ Media } & \multirow{3}{*}{$\begin{array}{c}\text { Sea- } \\
\text { water }\end{array}$} & \multirow[t]{3}{*}{ DDW } & \multicolumn{2}{|c|}{ Scored plates ${ }^{1}$} & \multicolumn{2}{|c|}{ Non-scored plates } & \multirow{3}{*}{$\begin{array}{c}\text { Liquid media } \\
24 \mathrm{~h} \\
\text { light }\end{array}$} & \multirow[t]{3}{*}{$\mathrm{pH}$} \\
\hline & & & $12: 12 \mathrm{~h}$ & $24 \mathrm{~h}$ & $12: 12 \mathrm{~h}$ & $24 \mathrm{~h}$ & & \\
\hline & & & light:dark & light & light:dark & & & \\
\hline Grund $^{\mathrm{a}}$ & $\mathrm{v}$ & & $(++)$ & $(+++)$ & $(+)$ & $(+)$ & $(+++)$ & $8.1-8.3$ \\
\hline ASN-III ${ }^{\mathrm{b}}$ & & $\mathrm{v}$ & $(++)$ & $(++++)$ & $(+)$ & $(+)$ & $(+++)$ & $8.1-8.3$ \\
\hline$f / 2^{c}$ & $\mathrm{v}$ & & $(-)$ & $(+)$ & $(-)$ & $(-)$ & $(-)$ & $8.1-8.3$ \\
\hline $\mathrm{MN}^{\mathrm{d}}$ & $\mathrm{v}$ & & $(-)$ & $(+)$ & $(-)$ & $(-)$ & $(-)$ & $8.1-8.3$ \\
\hline $\mathrm{SN}^{\mathrm{e}}$ & $\mathrm{v}$ & $\mathrm{v}$ & $(-)$ & $(+)$ & $(-)$ & $(-)$ & $(-)$ & $8.1-8.3$ \\
\hline BG-11 Na2S ${ }^{f}$ & $\mathrm{v}$ & $\mathrm{v}$ & $(-)$ & $(+)$ & $(-)$ & $(-)$ & $(-)$ & 9 \\
\hline $\mathrm{Na} 2 \mathrm{~S}^{\mathrm{g}}$ & $\mathrm{v}$ & & $(-)$ & $(+)$ & $(-)$ & $(-)$ & $(-)$ & $8.1-8.3$ \\
\hline PCR-S8 ${ }^{\mathrm{h}}$ & & $\mathrm{v}$ & $(-)$ & $(+)$ & $(-)$ & $(-)$ & $(-)$ & $8.1-8.3$ \\
\hline PCR-S11 ${ }^{\mathrm{h}}$ & & $\mathrm{v}$ & $(-)$ & $(-)$ & $(-)$ & $(-)$ & $(-)$ & $8.1-8.3$ \\
\hline PCR-Tu $2^{\text {h }}$ & & $\mathrm{v}$ & $(-)$ & $(-)$ & $(-)$ & $(-)$ & $(-)$ & $8.1-8.3$ \\
\hline BG- $11^{i}$ & $\mathrm{v}$ & $\mathrm{v}$ & $(-)$ & $(+)$ & $(-)$ & $(-)$ & $(-)$ & $8.1-8.3$ \\
\hline Erdschreiber ${ }^{\mathrm{j}}$ & $\mathrm{v}$ & & $(-)$ & $(+)$ & $(-)$ & $(-)$ & $(-)$ & $8.1-8.3$ \\
\hline Zoox. broth ${ }^{\mathrm{k}}$ & $\mathrm{v}$ & & & & & & $(+++++)$ & $8.1-8.3$ \\
\hline \multicolumn{9}{|c|}{${ }^{\mathrm{a}}$ von Stosch $(1963,1969)$ supplemented with $1 \mathrm{~g} \mathrm{l}^{-1} \mathrm{NaNO}_{3}$} \\
\hline \multirow{2}{*}{\multicolumn{9}{|c|}{${ }^{\mathrm{b}}$ Waterbury \& Stanier (1981) supplemented with $1 \mathrm{~g} \mathrm{l}^{-1} \mathrm{NaNO}_{3}$}} \\
\hline \multicolumn{8}{|c|}{${ }^{\mathrm{C}}$ Guillard \& Ryther (1962) } & \\
\hline \multicolumn{9}{|c|}{${ }^{\mathrm{d}}$ Waterbury \& Stanier (1981) } \\
\hline \multirow{2}{*}{\multicolumn{9}{|c|}{$\begin{array}{l}\text { eWaterbury \& Willey (1988); } 11 \text { medium was prepared by mixing } 750 \mathrm{ml} \text { of filtered seawater with } 250 \mathrm{ml} \text { autoclaved DDW } \\
{ }^{\mathrm{f}} \mathrm{BG}-11 \text { supplemented with } 0.1 \% \text { (wt/vol) } \mathrm{Na}_{2} \mathrm{~S} \cdot 9 \mathrm{H}_{2} \mathrm{O} \text { (Vaara et al. 1979) and adjusted to } \mathrm{pH} 9\end{array}$}} \\
\hline & & & & & & & & \\
\hline \multicolumn{9}{|c|}{${ }^{9}$ Cohen et al. (1975). Medium is prepared with filtered seawater, $750 \mathrm{mg} \mathrm{l}^{-1} \mathrm{Na}_{2} \mathrm{~S} \cdot 9 \mathrm{H}_{2} \mathrm{O}$ at $\mathrm{pH} 8.1-8.3$} \\
\hline \multicolumn{9}{|c|}{${ }^{\mathrm{h}}$ Rippka et al. (2000). Seawater was filter sterilized } \\
\hline \multicolumn{9}{|c|}{$\begin{array}{l}{ }^{\mathrm{B}} \text { BG11 is a freshwater medium (Allen \& Stanier 1968). For this study BG-11 was prepared by mixing } 750 \mathrm{ml} \text { of filtered sea- } \\
\text { water with } 250 \mathrm{ml} \text { autoclaved DDW }\end{array}$} \\
\hline \multicolumn{9}{|c|}{ jSchreiber (1927), Føyn (1934) } \\
\hline \multicolumn{9}{|c|}{$\begin{array}{l}\text { kZooxanthelae broth was prepared by autoclaving coral tissue in seawater and filtering through a } 0.22 \mu \mathrm{m} \text { filter. Solution was } \\
\text { supplemented with } 1 \mathrm{ml} \times 1000 \text { vitamin mix and } 1 \mathrm{ml} \text { micronutrient mix }\end{array}$} \\
\hline${ }^{1}$ Plates were sc & d (Vaara & al. 1979) & vith parallel l & using a flo & d glass and ke & & rectional light & \\
\hline
\end{tabular}

not result in enhanced motility. Nevertheless, strains isolated from infected corals demonstrated an ability to survive in higher concentrations of $\mathrm{Na}_{2} \mathrm{~S}(750 \mathrm{mg}$ $\mathrm{Na}_{2} \mathrm{~S} \cdot 9 \mathrm{H}_{2} \mathrm{O} \mathrm{l}^{-1}$ of medium). In liquid media, filaments concentrated in clumps on the glass walls of flasks. They formed a straight line at the interface between media and air while orienting towards the light. Placement of a sterile piece of coral skeleton in the flasks initiated settlement of the filaments onto the skeleton.

Pigmentation and morphology of strains. Both BBD(Fig. 1a) and red band- (Fig. 1b) infected corals sampled in Palau exhibited a clear band at the interface between coral tissue and skeleton. High light magnification $(\times 1000)$ of cyanobacterial filaments derived from both BBD (Fig. 2a) and red bands (Fig. 2b) show clear segmentation between individual cells. Filaments appear to be similar in diameter, with rounded cells along the edges and at the ends of filaments. The length of individual cells within a filament is variable. Filaments isolated from BBD appear to gain pigmentation from black/brown granulation within each cell (see Fig. 2a). Red pigmentation in filaments isolated from red band-infected corals (Fig. 2b) is more evenly distributed, making it more difficult to discern whether this is caused by granulation.

Isolates from red band-infected corals remained red in liquid culture (ASN-III, continuous illumination at $26^{\circ} \mathrm{C}$ ) for 10 to $12 \mathrm{wk}$ until initial signs of chlorosis began to appear. At this point, red pigmentation paled to a light red color. Isolates from BBD-infected coral maintained under the same growth conditions, remained dark in culture for a shorter period (4 to $6 \mathrm{wk}$ ) before undergoing chlorosis. They became pale green before turning completely colorless and transparent.

Taxonomic identity of strains. All 3 cyanobacterial cultures isolated from corals in Palau produced identical partial 16S rDNA gene sequences (582 bp) (Table 2). All 3 isolated cyanobacteria demonstrated 99\% 16S rDNA sequence identity with an uncultured cyanobacterial strain (AF473936) associated with BBD-infected corals in the Caribbean that has been previously identified by molecular analyses (Cooney et al. 2002). 

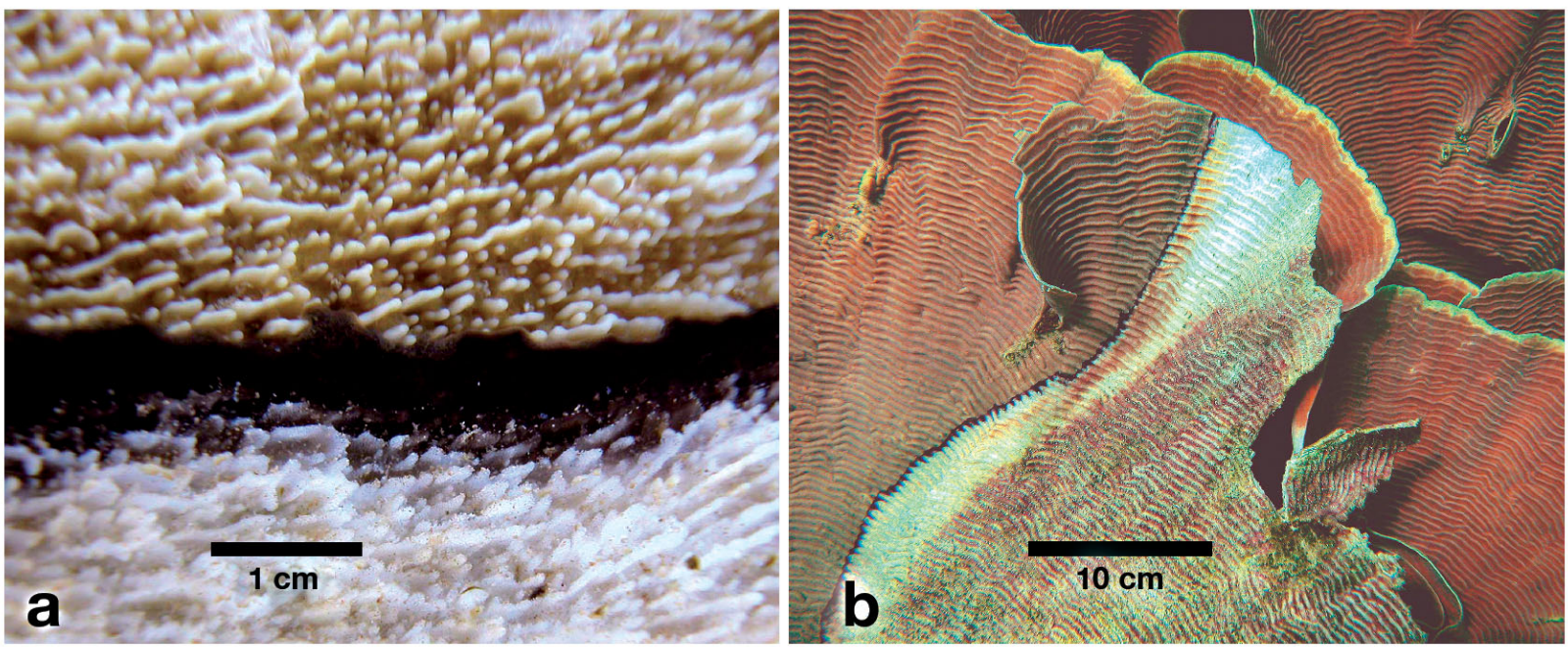

Fig. 1. Montipora sp. and Pachyseris speciosa. Cyanobacterial infections on corals collected from Palaun reefs. (a) Montipora sp. with black band disease (BBD); (b) P. speciosa with red band
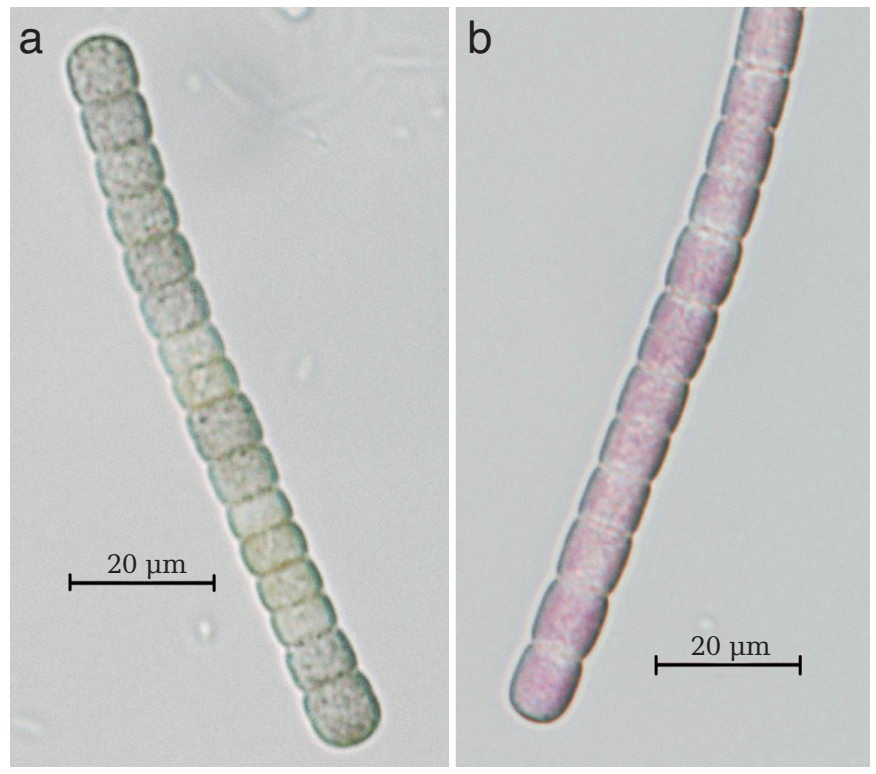

Fig. 2. Filamentous cyanobacteria isolated and cultured from (a) Montipora sp. with BBD and (b) Pachyseris speciosa with red band. (a) Dark granulation observed in individual cells. Segmentation in both filaments is clear. Red pigmentation in (b) is maintained under identical growth conditions as (a). Red pigmentation is more evenly distributed along the filament

\section{DISCUSSION}

Results reported here represent the first successful isolation and culturing of filamentous cyanobacteria associated with both red band- and BBD-infected corals. Our molecular studies show that cyanobacterial filaments isolated from corals infected with red band and BBD share the same taxonomic identity. Observations of cyanobacteria in culture suggest that a single cyanobacterial ribotype associated with a coral disease can exhibit dual pigmentation under similar light and growth conditions. Previous studies of cyanobacterial pigmentation have demonstrated that complementary chromatic adaptation allows cyanobacteria to reversibly alter their pigmentation from green-blue to red in response to light (see reviews by Grossman et al. 1993a,b). This has been demonstrated in the filamentous cyanobacterium Fremyella diplosiphon (Kehoe \& Grossman 1994). The color of cells can also be a response to other environmental factors, such as elevated or low nutrient levels (nitrogen, phosphorus and sulfur; Collier \& Grossman 1992).

Consistency of color, either red or brown/black, of cyanobacteria cultured over the 12 wk of our study suggests that complementary chromatic adaptation does not adequately explain our observations. Had light and growth conditions determined color expression, a complementary chromatic adaptation should have occurred and both red and brown/black cyanobacterial cultures would have converged to a similar pigmentation. The only shift in pigmentation suggestive of a complementary chromatic adaptation that we observed was from red to light green in some cultures growing on agar plates. This change was usually rapid and irreversible. Red cyanobacteria from red band-infected corals never exhibited the dark brown/ black pigmentation seen in the cultures originating from BBD-infected corals. Synechococcus sp. strain SH-94-5 reacts to nitrogen depletion by upregulating the accumulation of beta-carotene, thus resulting in a pigmentation change to red. During exponential growth, this strain down regulates production of phycobiliproteins and becomes green (Miller et al. 2002). Whether such pigmentation changes occur in cyano- 
Table 2. Properties of cyanobacterial strains associated with red band- and BBD-infected corals from Palau

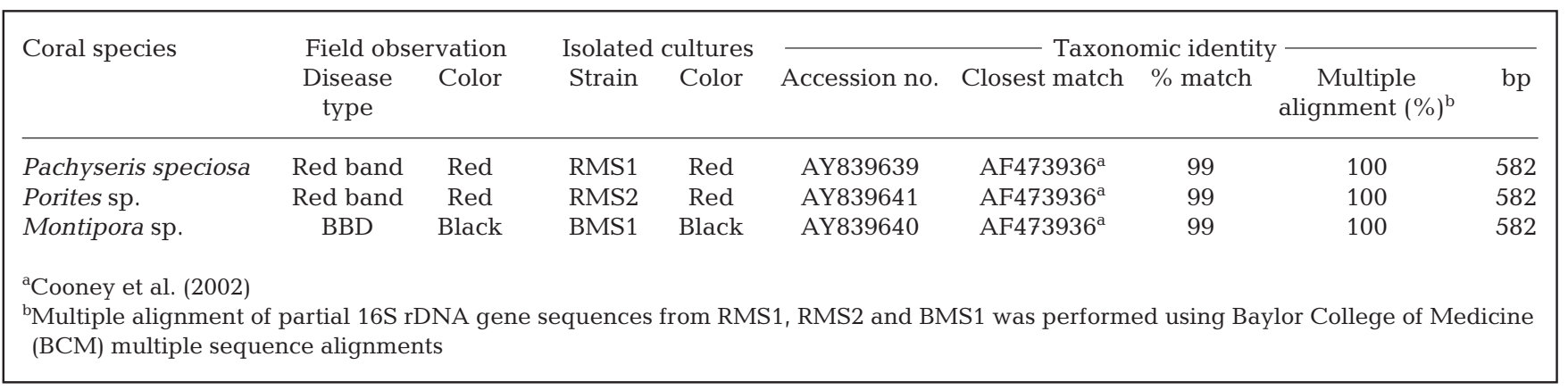

bacteria infesting coral tissue in the field remains unknown. Currently, there are no reports of BBDinfected corals transforming into red bands, or red bands transforming into black bands.

Two lines of evidence suggest that cyanobacterial growth in culture is optimized by the presence of substrate for settlement. First, cyanobacterial strains grown in liquid cultures settled on the glass flasks along a line at the interface between the liquid media and air and starting at the side closest to the light. Secondly, addition of a sterile piece of coral skeleton to the media flasks initiated immediate settlement of the filaments. This preference for substrate might explain why shaking of cultures in liquid media has proven unsuccessful for growth. However, settlement of cyanobacterial filaments on coral skeletons in the laboratory was different from settlement observed in the field, where filaments concentrate only at the interface between coral tissue and skeleton, leaving a white exposed skeleton behind the moving front (as in Fig. 1). The settlement pattern observed in the laboratory is possibly explained by the distribution of nutrients inside media flasks. Cyanobacteria progressing along the border of degrading coral tissue are exposed to high nutrient levels (Taylor 1983). The high density of filaments forming the bands on infected corals also results in shading (Richardson et al. 2001), although there are conflicting reports of bands progressing either towards the light or away from it (Antonius 1981). Filament aggregation was suggested by Castenholz (1982) as a mechanism adopted by cyanobacteria to increase shading in order to attain lower light levels needed for optimal photosynthetic activity. In our laboratory trials, in contrast, filaments tended to dissociate when placed in grooves on scored agar plates, with individual filaments separating and traveling up to $5 \mathrm{~cm} \mathrm{~d}^{-1}$ towards the light, eventually spreading over the entire agar surface rather than aggregating.

The speed with which cyanobacterial filaments isolated from both red band- and BBD-infected corals travel across agar indicates that band-progression in the field (only 0.3 to $1 \mathrm{~cm} \mathrm{~d}^{-1}$ ) might be limited by other factors. The degree of motility of filaments in this study might explain how members of this taxonomic ribotype outcompete other cyanobacteria when settling on corals. Further study should be directed at determining the relationship between motility towards light and the propensity for aggregation and at how these might be affected by variation in light and nutrient levels.

As in previous studies that have attempted to determine the identity of filamentous cyanobacteria associated with BBD (Cooney et al. 2002, Frias-Lopez et al. $2002,2003)$, this study used partial sequencing of the $16 \mathrm{~S}$ rDNA gene. Given that we sampled only 2 red bands from the field, our results do not imply that all red band infections carry the same cyanobacteria; further samples from red bands are required to test the generality of our results. Although we have shown that dual pigmentation can be exhibited by a single ribotype, other less dominant cyanobacterial strains that we were unable to isolate and culture on the media used may have been present in our original field samples. Our aim in this study was to isolate and culture the dominant color-forming strains from infected corals in the field, and to establish a reference point in the relation between cyanobacterial color, taxonomic identity and disease classification, rather than to identify the entire microbial complexity of cyanobacterial mats on infected corals. Cloning of extracted DNA from field samples using universal primers targeted at a larger region of the $16 \mathrm{~S}$ rDNA gene would provide a more comprehensive analysis of cyanobacterial populations associated with both red band- and BBD-infected corals. If pathogenicity and virulence are to be studied, an attempt should be made to explore the genes linking identity and function, as has been recently demonstrated for BBD by Frias-Lopez et al. (2004a). In the case of Vibrio cholera it has already been shown that the 16S rDNA based identity of strains does not necessarily relate to virulence (Colwell \& Huq 1994, Singh et al. 2001).

This study has identified dual pigmentation expressed by a single ribotype found on both red band- 
and BBD-infected corals but did not determine the mechanism involved. The fact that red bands are far less prevalent in the field than BBD, might point towards a genetic variation that results in both a common and a rare phenotype.

The strains isolated and cultured by this study belong to a ribotype that has been previously identified by molecular tools on BBD-infected corals in the Caribbean (Cooney et al. 2002, Frias-Lopez et al. 2002). The strains isolated from both red bands and BBD in this study were found by BLAST to share less than $90 \%$ match-identity with Phormidium corallyticum, previously suggested as the causative agent of BBD. The results of this study support the call for re-examination of the role of $P$. corallyticum in BBD infections by comparing its ability to infect healthy corals with the newly isolated strains presented here (RMS1, RMS2 and BMS1).

The maintenance of new cultures associated with coral disease opens many doors for further research, including examining the potential virulence and toxicity of these new strains isolated from red bands and BBD, their geographical distribution and the ways in which strains are transmitted. Based on the results of this study, we strongly urge postponing the classification of red cyanobacterial bands as a separate coral disease until further evidence is collected.

Acknowledgements. This study was made possible by a James Cook University (JCU) Competitive Research Incentive Grant to B.W. Field trip and sample collection were part of the annual IOC-GEF/WB Disease Working Group meeting held in Palau (25 January to 6 February, 2004). The authors thank A. Hooten from the IOC-GEF/WB Coral Reef Targeted Research and Capacity Building Program and Prof. C. D. Harvell, Chair of the WB/Coral Disease Working Group, for funding travel and field work. The authors thank members of the Palau International Coral Reef Center (PICRC) for their help in sample collection. Special thanks to Prof. L. Raymundo and Prof. G. Smith for samples of infected corals. The underwater photograph of Pachyseris speciosa infected with red band was generously provided by Dr. F. Croquer. Molecular and microbial work was performed at and partially funded by the Australian Institute for Marine Science (AIMS). Sequencing was performed by the Advanced Analytical Centre at JCU. Special thanks to L. Woodward (JCU) and N. Young (AIMS) for assistance with sequencing and microscopy.

\section{LITERATURE CITED}

Allen MM, Stanier RY (1968) Selective isolation of blue-green algae from water and soil. J Gen Microbiol 51(2):203-9

Altschul SF, Gish W, Miller W, Myers EW, Lipman DJ (1990) Basic local alignment search tool. J Mol Biol 215:403-410

Antonius A (1973) New observations on coral destruction in reefs. In: 10th Meeting of the Association of Island Marine Laboratories of the Caribbean, Sep 4-7, 1973. Dept of Marine Sciences, University of Puerto Rico, Mayaguez

Antonius A (1981) The 'band' diseases in coral reefs. Proc 4th Int Coral Reef Symp 2:7-14
Castenholz RW (1982) Motility and taxes. In: Carr NG, Whitton BA (eds) The biology of cyanobacteria. University of California Press, Berkeley, p 413-440

Cohen Y, Padan E, Shilo M (1975) Facultative anoxygenic photosynthesis in the cyanobacetrium Oscillatoria limnetica. J Bacteriol 123(3):855-861

Collier JL, Grossman AR (1992) Chlorosis induced by nutrient depravation in Synechococcus sp. Strain PCC 7942: not all bleaching is the same. J Bacteriol 174(14):4718-4726

Colwell RR, Huq A (1994) Environmental reservoir of Vibrio cholera: the causative agent of cholera. Ann NY Acad Sci 740:44-54

Cooney RP, Pantos O, Tissier MDAL, Barer MR, O'Donnell AG, Bythell JC (2002) Characterization of the bacterial consortium associated with black band disease in coral using molecular microbiological techniques. Environ Microbiol 4:401-413

Føyn B (1934) Lebenszyklus, Cytologie und Sexualität der Chlorophycee Cladophora suhriana Kutzing. Arch Protistenkd 83:1-56

Frias-Lopez J, Zerkle AL, Bonheyo GT, Fouke BW (2002) Partitioning of bacterial communities between seawater and healthy, black band diseased, and dead coral surfaces. Appl Environ Microbiol 68:2214-2228

Frias-Lopez J, Bonheyo GT, Jin Q, Fouke BW (2003) Cyanobacteria associated with coral black band disease in Caribbean and Indo-Pacific Reefs. Appl Environ Microbiol 69(4):2409-2413

Frias-Lopez J, Bonheyo GT, Jin Q, Fouke BW (2004a) Identification of differential gene expression in bacteria associated with coral black band disease by using RNA-arbitrarily primed PCR. Appl Environ Microbiol 70 (6):3687-3694

Frias-Lopez J, Klaus JS, Bonheyo GT, Fouke BW (2004b) Bacterial community associated with black band disease in corals. Appl Environ Microbiol 70(10):5955-5962

Garzon-Ferreira J, Gil-Agudelo DL, Berrios ML, Zea S (2001) Stony coral diseases observed in southwestern Caribbean reefs. In: Porter JW (ed) The ecology and etiology of newly emerging marine diseases. Developments in hydrobiology. Kluwer, Dordrecht, p 65-69

Grossman AR, Schaefer MR, Chiang GG, Collier JL (1993a) Environmental effects on the light-harvesting complex of cyanobacteria. J Bacteriol 175 (3):575-582

Grossman AR, Schaefer MR, Chiang GG, Collier JL (1993b) The phycobilisome, a light-harvesting complex responsive to environmental conditions. Microbiol Rev 57(3):725-749

Guillard RRL, Ryther JH (1962) Studies of marine planktonic diatoms. I. Cyclotella nana Hustedt and Detonula confervacea (Cleve) Gran. Can J Microbiol 8:229-239

Harvell D, Aronson R, Baron N, Connell J and 13 others (2004) The rising tide of ocean diseases: unsolved problems and research priorities. Front Ecol Environ 2(7): 375-382

Kehoe DM, Grossman AR (1994) Complementary chromatic adaptation: photoperception to gene regulation. Semin Cell Biol 5(5):303-313

Lesser MP, Mazel CH, Gorbunov MY, Falkowski PG (2004) Discovery of symbiotic nitrogen-fixing cyanobacteria in corals. Science 305(5686):997-1000

McLachlan J (1973) Growth media - marine. In: Stein JR (ed) Handbook of phycological methods, culture methods and growth measurements. Cambridge University Press, Cambridge, p 25-51

Miller SR, Martin M, Touchton J, Castenholz RW (2002) Effects of nitrogen availability on pigmentation and carbon assimilation in the cyanobacterium Synechococcus sp. strain SH-94-5. Arch Microbiol 177:392-400 
Nubel U, Garcia-Pichel F, Muyzer G (1997) PCR primers to amplify 16S rDNA genes from cyanobacteria. Appl Environ Microbiol 63(8):3327-3332

Page C, Willis B (2006) Distribution, host range and largescale spatial variability in black disease prevalence on the Great Barrier Reef, Australia. Dis Aquat Org 69:41-51 (this issue)

Provasoli L (1963) Growing marine seaweeds. Proc Int Seaweed Symp 4:9-17

Richardson LL (1992) Red band disease: a new cyanobacterial infestation of corals. In: Cahoon LB (ed) Proc 10th Am Acad Underw Sci Sep 24-27, 1992, Wilmington, NC. American Academy of Underwater Sciences, Costa Mesa, CA, p 153-160

Richardson LL (1997) Occurrence of the black band disease cyanobacterium on healthy corals of the Florida keys. Bull Mar Sci 61(2):485-490

Richardson LL (1998) Coral diseases: What is really known? Trends Ecol Evol 13:438-443

Richardson LL, Smith GW, Ritchie KB, Carlton RG (2001) Integrating microbiological, microsensor, molecular and physiologic techniques in the study of coral disease pathogenesis. Hydrobiologia 460:71-89

Richardson LL (2004) Black band disease. In: Rosenberg E, Loya Y (eds) Coral health and disease. Springer, Heidelberg, p 325-336

Rippka R, Deruelles J, Waterbury JB, Herdman M, Stanier RY (1979) Generic assignments, strain histories and properties of pure cultures of cyanobacteria. J Gen Microbiol 111:1-61

Rippka R, Coursin T, Hess W, Lichtle C and 6 others (2000) Prochlorococcus marinus Chishol et al. 1992 subsp. pastoris subsp. nov. strain PCC 9511, the first axenic chlorophyll $\mathrm{a}_{2} / \mathrm{b}_{2}$-containing cyanobacterium (Oxyphotobacteria). Int J Sys Evol Microbiol 50:1833-1847

Rützler K, Santavy DL (1983) The black band disease of Atlantic reef corals. I. Description of the cyanophyte pathogen. PSZN I: Mar Ecol 4:301-319

Rützler K, Santavy DL, Antonius A (1983) The black-band disease of Atlantic reef corals. III. Distribution, ecology and development. PSZN I: Mar Ecol 4:329-358

Santavy D, Peters E (1997) Microbial pests: coral disease in

Submitted: November 28, 2004; Accepted: June 28, 2005 the Western Atlantic. Proc 8th Int Coral Reef Symp 1:607-612

Schreiber E (1927) Die Reinkultur von marinem Phytoplankton und deren Bedeutung für die Erforschung der Produktionsfähigkeit des Meerwassers. Wiss Meeresuntersuch 16:1-34

Singh DV, Matte MH, Matte GR, Jiang S and 5 others (2001) Molecular analysis of Vibrio cholera O1, O139, non-O1, and non-O139 strains: clonal relationships between clinical and environmental isolates. Appl Environ Microbiol (67)2:910-921

Sutherland KP, Porter JW, Torres C (2004) Disease and immunity in Caribbean and Indo-Pacific zooxanthellate corals. Mar Ecol Prog Ser 266:273-302

Taylor DL (1983) The black band disease of Atlantic reef corals II. Isolation, cultivation and growth of Phormidium corallyticum. PSZN I: Mar Ecol 4:321-328

Vaara T, Vaara M, Niemela S (1979) Two improved methods for obtaining axenic cultures of cyanobacteria. Appl Environ Microbiol 38(5):1011-1014

von Stosch HA (1963) Wirkung von Jod und Arsenit auf Meeresalgen in Kultur. Proc Int Seaweed Symp 4:142-150

von Stosch HA (1969) Observations on Corallina, Jania and other red algae in culture. Proc Int Seaweed Symp 6: 389-399

Waterbury JB, Stanier RY (1981) In: Starr MP, Stolp H, Truper HG, Balows A, Schlegel HG (eds) The Prokaryotes, Vol 1. Springer, Berlin, p 221

Waterbury J, Willey J (1988) Isolation and growth of marine planktonic cyanobacteria. Methods Enzymol 167:100-105

Weil E, Urreiztieta I, Garzon-Ferreira (2002) Geographic variability in the incidence of coral and octocoral disease in the wider Caribbean. Proc 9th Int Coral Reef Symp 2:1231-1238

Weil E (2004) Coral reef diseases in the wider Caribbean. In: Rosenberg E, Loya Y (eds) Coral health and disease. Springer, Heidelberg, p 35-68

Willis BL, Page CA, Dinsdale EA (2004) Coral disease on the Great Barrier Reef. In: Rosenberg E, Loya Y (eds) Coral health and disease. Springer, Heidelberg, p 69-104

Wu X, Zarka A, Boussiba S (2000) A simplified protocol for preparing DNA from filamentous cyanobacteria. Plant Mol Biol Rep 18:385-392

Proofs received from author(s): March 6, 2006 